\title{
Influence of biota on spatial and temporal variation in sediment erodability and material flux on a tidal flat (Westerschelde, The Netherlands)
}

\author{
J. Widdows ${ }^{1, *}$, M. D. Brinsley ${ }^{1}$, P. N. Salkeld ${ }^{1}$, C. H. Lucas ${ }^{2}$ \\ ${ }^{1}$ Centre for Coastal and Marine Sciences, Plymouth Marine Laboratory, Prospect Place, The Hoe, Plymouth PL1 3DH, \\ United Kingdom \\ ${ }^{2}$ School of Ocean and Earth Science, University of Southampton, Southampton Oceanography Centre, European Way, \\ Southampton SO14 3ZH, United Kingdom
}

\begin{abstract}
Annular flumes were used to quantify benthic-pelagic exchanges in relation to changes in current velocity and sediment biota. Various physical, chemical and biological parameters were determined for 4 sites on the Molenplaat tidal flat in the Westerschelde (The Netherlands) during 2 field campaigns in May-June and August-September 1996. These included: the mass of sediment eroded, maximum and mean erosion rates, critical erosion velocity $\left(\bar{U}_{\text {crit }}\right)$, suspension feeding/biodeposition rate, oxygen and ammonium fluxes, density of macrofauna species, chlorophyll a (chl a), colloidal carbohydrate, and physical properties of the sediment. The study showed marked and statistically significant spatial and temporal differences in the potential for sediment erosion. Sites in the centre of the tidal flat were less erodable than those on the edge. All sites on the tidal flat had a significantly ( $p<$ 0.001 ) lower erosion potential in June (i.e. higher $\bar{U}_{\text {crit }}$ and lower erosion rates) compared to September. The presence of a well-developed microphytobenthos community in June resulted in a statistically significant relationship between $\bar{U}_{\mathrm{cnt}}$ and $\mathrm{chl}$ a/colloidal carbohydrate $(\mathrm{r}=+0.85, \mathrm{p}=0.01)$. There was a significant relationship $(r=+0.88, p=0.005)$ between sediment erodability (mass of sediment eroded and erosion rate) and the density of the clam Macoma balthica, a major bioturbator of the surface sediments. Analysis of the data also demonstrated significant relationships between clearance rate and Cerastoderma edule biomass $(\mathrm{r}=+0.91, \mathrm{p}<0.001)$, and between sediment chl a/colloidal carbohydrate and $C$. edule biomass $(r=+0.92 ; p<0.001)$, reflecting the influence of suspension feeders on both the water column and the sediment, through their biodeposits. The significant increase in sediment erodability between June and September reflected the shift in the overall balance between the major 'biostabilisers' (microphytobenthos) and 'bio-destabilisers' (bioturbating bivalves). This interpretation of field-derived correlations is consistent with previously established relationships and mechanistic understanding derived from controlled flume experiments.
\end{abstract}

KEY WORDS: Sediment erosion - Flumes - Benthic-pelagic exchange $\cdot$ Tidal flats $\cdot$ Benthic macrofauna $\cdot$ Microphytobenthos $\cdot$ Biodeposition $\cdot$ Westerschelde

\section{INTRODUCTION}

Tidal flats occupy large and significant areas of estuarine and sheltered coastal ecosystems. They are inhabited by complex and diverse biological communities which can play an important role in the metabolic processes and material fluxes within the estuary (Heip et al. 1995). However, the biogeochemical processes influencing estuarine tidal flats, particularly sediment

•E-mail: j.widdows@pml.ac.uk stability and benthic-pelagic exchanges, are poorly understood despite their ecological and economic importance in relation to fisheries, birds, natural sea defences, shipping and as a sink for pollutants in industrialised estuaries.

At present there are no adequate models capable of predicting erosion, transport and deposition of fine sediments in estuaries. This is largely because the interactions between physical, chemical and biological processes are poorly quantified and understood. The role of biota as potential sediment stabilisers (e.g. ben- 
thic diatoms) and sediment destabilisers (e.g. bioturbators) has long been recognised (Rhoads \& Boyer 1982, Grant \& Daborn 1994, Paterson 1989, 1997), but few studies have considered the balance between the 2 functional groups and provided the quantitative understanding necessary for improving predictive models of estuarine sediment dynamics. There are relatively few techniques able to quantify sediment erosion, as well as other benthic-pelagic exchange processes, in relation to current velocity/shear stress and physical/biological properties of natural undisturbed sediments (techniques reviewed by Black \& Paterson 1997). Such measurements are necessary to assess the impact of biota on sediment stability/erodability and for the parameterisation of models of sediment dynamics. Recent field studies have shown that annular flume techniques are able to measure sediment erosion, and that marked spatial changes are a function of the biological properties of cohesive sediments (Amos et al. 1998. Widdows et al. 1998a).

The field study presented in this paper forms a component of the EU ELOISE ECOFLAT programme, a multi-disciplinary study of the complex interactions between physical, chemical and biological processes involved in the functioning of an estuarine tidal flat. The primary objective of this study was to quantify spatial and temporal changes in sediment erodability and material fluxes in relation to physical variables (sediment properties, current velocity) and biological factors (macrofauna and microphytobenthos). The study also investigates: (1) The hypothesis that the spatial and temporal variation in sediment erodability is influenced by the density/activity of biota and the overall balance between sediment 'stabilisers' and 'destabilisers'. (2) The importance of biologically mediated benthic-pelagic fluxes on the dynamics of estuarine tidal flats (i.e. suspension feeding and biodeposition, stabilisation/destabilisation of sediments). (3) The extent to which results from annular flume studies reflect resuspension/sedimentation processes measured directly in the field.

\section{MATERIALS AND METHODS}

Two 'ECOFLAT' field campaigns were carried out at the Molenplaat tidal flat (Fig. 1) in the Westerschelde (SW Netherlands) in the spring (28 May to 7 June 1996) and late summer (27 August to 5 September 1996). The Plymouth Marine Laboratory (PML) annular flumes (Widdows et al. 1998a,b) were used to quantify material fluxes and the erosion potential of sediment collected from 4 of the 5 sites (Sites 1, 2, 3 and 5; Fig. 1). Site 4 was not sampled for flume studies during 1996. The site locations were as follows: Site 1 (latitude $51^{\circ}$ 26.15', longitude $3^{\circ} 57.3^{\prime}$ ); Site 2 (latitude $51^{\circ} 26.30^{\prime}$, longitude $3^{\circ} 57.2^{\prime}$ ); Site 3 (latitude $51^{\circ} 26.25^{\prime}$, longitude $3^{\circ} 56.9^{\prime}$ ); Site 4 (latitude $51^{\circ} 26.40^{\prime}$, longitude $3^{\circ} 56.8^{\prime}$ ); Site 5 (latitude $51^{\circ} 25.90^{\prime}$, longitude $3^{\circ} 56.6^{\prime}$ ).

The annular flume and operating procedures have been described in detail by Widdows et al. (1998a,b). In summary, the flume represents a smaller, modified version of the design described by Fukada \& Lick (1980). The annular flume is constructed of acrylic material with a $64 \mathrm{~cm}$ (outer) and $44 \mathrm{~cm}$ (inner) diameter, resulting in a $10 \mathrm{~cm}$ channel width with a total bed area of $0.17 \mathrm{~m}^{2}$, a maximum water depth of $38 \mathrm{~cm}$, and a maximum volume of $60 \mathrm{l}$. Current velocities ranging
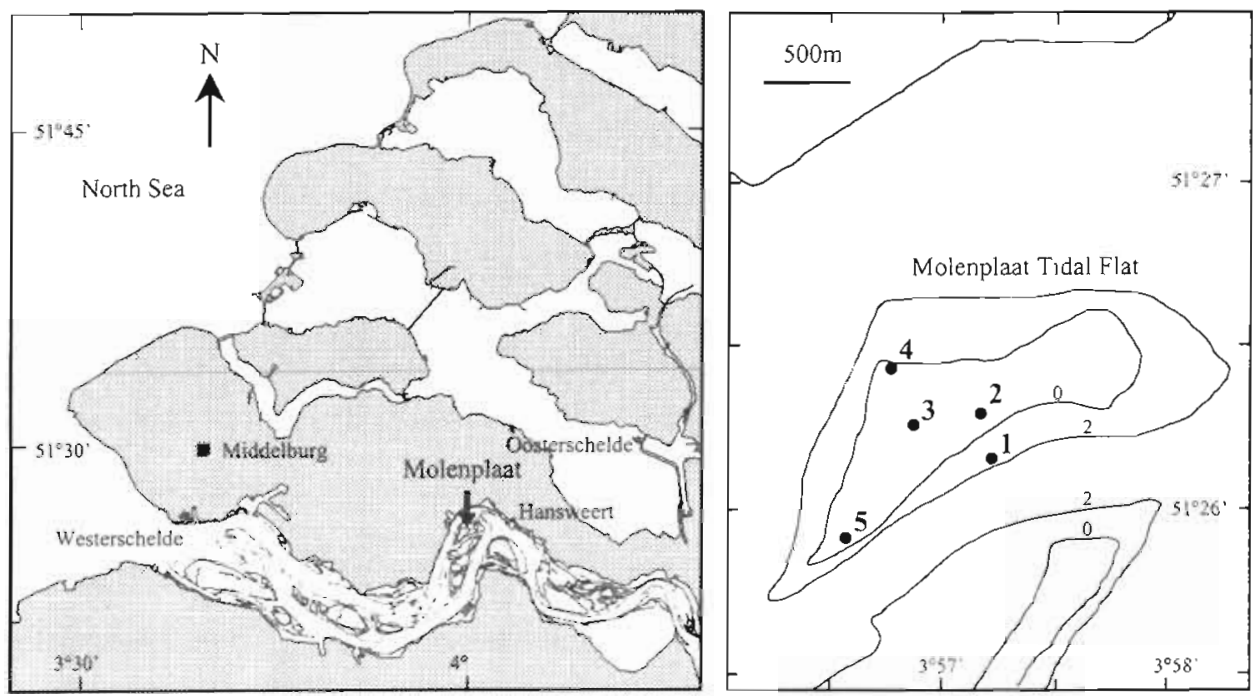

Fig. 1. Location of the Molenplat tidal flat and the sampling sites. Isolines represent low tide level (2) and mid-tide level (0) 
from 1 to $50 \mathrm{~cm} \mathrm{~s}^{-1}$ and bed shear stresses $(0.01$ to $2 \mathrm{~Pa})$ are generated by a rotating annular drive plate (a smooth surface without paddles) driven by a $12 \mathrm{~V}$ motor, with controller board and data logger, which is powered by two $12 \mathrm{~V}$ batteries. The drive plate speed is monitored using an infra-red photo switch and this is recorded every $15 \mathrm{~s}$ by the data logger. An electromagnetic (EM) current flow meter (Valeport Model 800-175) and video-tracking of neutrally buoyant particles have been used to measure free-stream current velocities and vertical profiles in the flume and to calibrate the rotation speed of the drive plate. The concentration of suspended particulate matter (SPM) in the flume is monitored using an optical back scatter sensor (OBS-3; D \& A Instruments) and the output (V) is recorded every $15 \mathrm{~s}$ by the data logger. The OBS sensor is calibrated against water samples taken for gravimetric analysis and calibration curves are produced for each experimental run for each site/sediment type.

During the first ECOFLAT field campaign (MayJune 1996), the annular flume was initially deployed in its 'in situ mode' during tidal exposure at Site 2, because the surface sediment was sufficiently silty' muddy to retain the water in the flume. However, following the erosion/resuspension of the sticky cohesive surface layer at current velocities of $30 \mathrm{~cm} \mathrm{~s}^{-1}$, the water was rapidly lost through the porous underlying sandy sediment. For details of in situ deployment of the flume see Widdows et al. (1998a,b).

Due to the porous nature of the Molenplaat sediment, all subsequent flume experiments were there- fore carried out in 'laboratory mode' on board a Rijkswaterstaat research vessel moored on the Molenplaat. At each site, sediment with its benthic community was cut into quadrant blocks (10 cm depth) and placed into polythene-lined trays, enabling it to be introduced into the laboratory flume (i.e. with fixed base) with minimal disturbance. In the second ECOFLAT field campaign, sediment was cored to a depth of $10 \mathrm{~cm}$ by means of stainless steel quadrant box cores ( 4 cores forming an annulus of $64 \mathrm{~cm}$ outer and $44 \mathrm{~cm}$ inner diameter) designed to fit precisely into the flume. The stainless steel quadrant cores were first pushed into the sediment and then dug out, allowing base plates to be inserted at the bottom of the cores. This enabled the cores to be lifted, and bands to be placed around them to retain the base and sediment during transportation to the flume. The quadrant box cores were carefully inserted into the annular flume and the stainless steel boxes were then removed, leaving the sediment and base plates in the flume. The sediment blocks were then carefully pushed together to fill any small gaps and the final space filled with a slice of sediment from an additional core. Such coring methods enable the surface features (e.g. ripples, worm casts, microphytobenthic film), burrowing macrofauna within the top $10 \mathrm{~cm}$, and the natural sediment stratification to be retained. Previous unpublished studies in the Humber estuary (England) have shown that there are no significant differences between the in situ flume measurements and laboratory-based measurements using quadrant box cored sediment (Fig. 2).

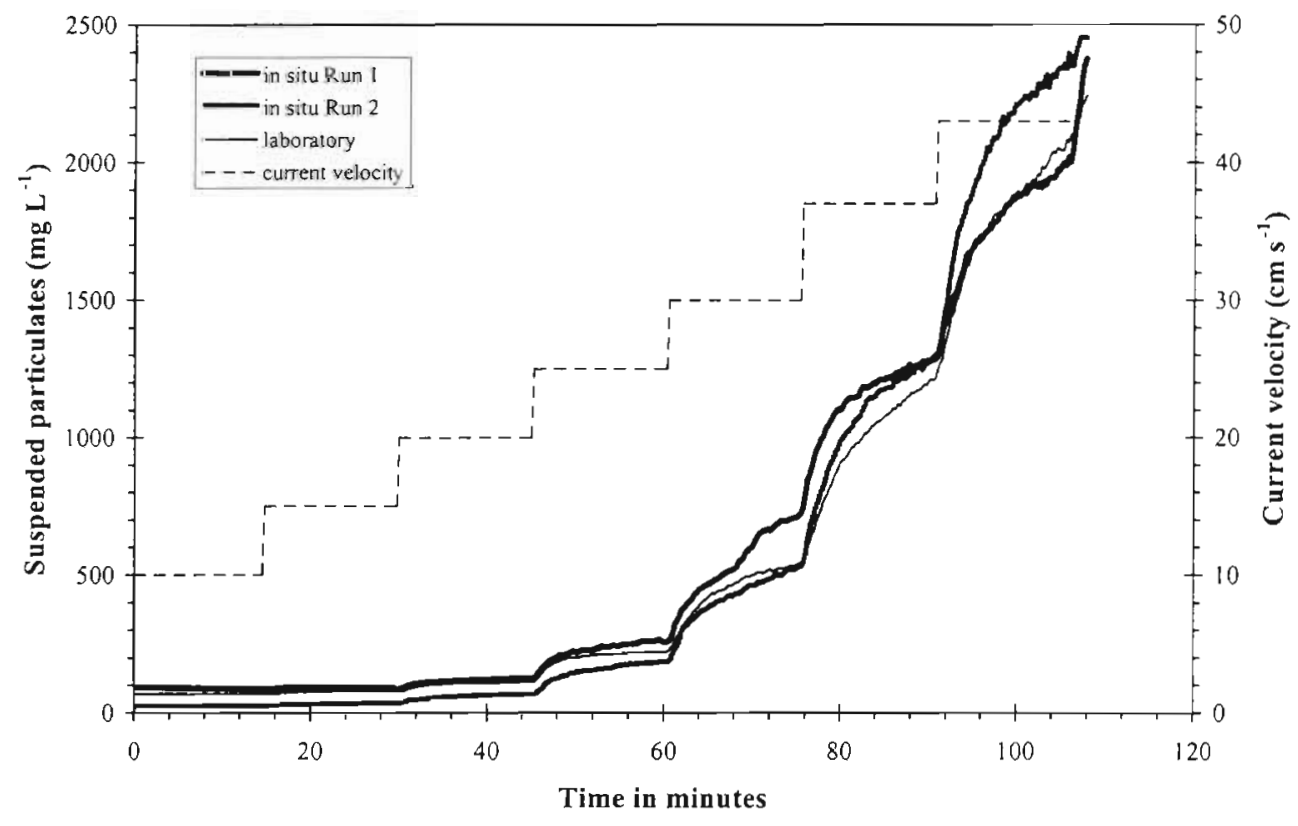

Fig. 2. Comparison between annular flume sediment erosion measurements performed in situ at Skeffling mudflat in the Humber estuary (replicated) and those performed in the laboratory within $3 \mathrm{~h}$ of coring sediment (quadrant cores) and placing in the flume 
There are 2 phases to the measurement of material flux across the sediment-water interface: Phase 1 (30 to 40 min duration) is conducted under conditions of low current velocity $\left(5 \mathrm{~cm} \mathrm{~s}^{-1}\right)$ and quantifies the clearance rate or the removal of suspended particles from the water column. This process will be enhanced by the suspension-feeding activity of benthic macrofauna and their net clearance rate $\left(\mathrm{CR} \mathrm{h}^{-1}\right)$ is determined from the difference between the clearance rate in the flume and in the 'control' (i.e. water column without sediment and benthic fauna). The clearance rate is calculated using the following equation:

$$
\mathrm{CR}\left(1 \mathrm{~h}^{-1}\right)=V\left(\log _{\mathrm{e}} C_{1}-\log _{\mathrm{e}} C_{2}\right) / t
$$

where, $V$ is the volume of water in the flume (l), $t$ is the time interval in $h$, and $C_{1}$ and $C_{2}$ are the volumes of suspended particles (between 3.2 and $12.1 \mu \mathrm{m}$ equivalent spherical diameter) at the beginning and end of each time increment (10 min intervals). Particles within this size range form a large proportion of the total particle volume and provide consistent counts. Water samples are taken by syringe from the middle of the water column in the flume and control. The volumes of suspended particles are determined by means of an electronic particle counter, Coulter Counter Multisizer, using a $100 \mu \mathrm{m}$ orifice tube. Net clearance rates of suspended particles (Phase 1) are then calculated from the exponential decline in the suspended particle concentration in the flume compared with the control chamber. Previous studies have confirmed that there are no significant differences between the clearance/sedimentation rates in a flume without fauna and a 'control cylinder' within the first 30 to $45 \mathrm{~min}$. Filtration or biodeposition rates are then calculated as follows:

Biodeposition rate $\left(\mathrm{g} \mathrm{m}^{-2} \mathrm{~h}^{-1}\right)=(\mathrm{CR})(\mathrm{SPM})(1 / \mathrm{A})$

where $C R$ is the net clearance rate $\left(\mathrm{l} \mathrm{h}^{-1}\right), \mathrm{SPM}$ is the mean suspended particulate matter concentration $\left(\mathrm{g}^{-1}\right)$ in Westerschelde seawater at the Molenplaat, and $A$ is the flume area of $0.17 \mathrm{~m}^{2}$.

Phase 2 (2.5 h duration) quantifies the SPM concentrations ( $\left.\mathrm{mg} \mathrm{l}^{-1}\right)$, mass of sediment eroded $\left(\mathrm{g} \mathrm{m}^{-2}\right)$ and the sediment erosion rate $\left(\mathrm{g} \mathrm{m}^{-2} \mathrm{~s}^{-1}\right)$ in response to step-wise increase in current velocity from 10 to $50 \mathrm{~cm}$ $\mathrm{s}^{-1}$, in $5 \mathrm{~cm} \mathrm{~s}^{-1}$ increments, each with a duration of 15 min. During Phase 2, the resuspension of sediment was determined by frequent monitoring (i.e. $15 \mathrm{~s}$ intervals) of the OBS output in volts. Maximum erosion rate ( $\left.E_{\text {max }}\right)$ occurs within 1 to 2 min after a step-wise increase in current velocity, and the mean erosion rate ( $\left.E_{\text {mean }}\right)$ is calculated over the first 10 min at each current velocity. Measurements are also supplemented by video recording (Sony $\mathrm{Hi}-8$ ) of observed phenomena and processes within the flume.
The relationship between measured free-stream current velocity (i.e. $10 \mathrm{~cm}$ above the bed) and estimated bed shear stress (based on log vertical profile $1 \mathrm{~cm}$ above the bed when smooth turbulent flow over finegrain cohesive mud) is described by the following equation:

$$
\begin{aligned}
& \text { Shear stress }(\mathrm{Pa})=0.0008 \bar{U}^{2}-0.0006 \bar{U}+0.0052 \\
& \left(\mathrm{r}^{2}=0.99\right)
\end{aligned}
$$

where $\bar{U}=$ mean free-stream current velocity $\left(\mathrm{cm} \mathrm{s}^{-1}\right)$. Calculation of shear stress is based on a log profile of current velocity within $1 \mathrm{~cm}$ above the bed. EM current meter measurements and video-tracking of suspended particles show that free-stream current velocities are constant down the water column to within $1 \mathrm{~cm}$ of the sediment surface. These observations confirm vertical profiles recorded in annular flumes by previous researchers (e.g. Fukada \& Lick 1980, Maa 1990). In the present study, the results are related to current velocities in preference to shear stress as the former parameter can be quantified directly and with a greater degree of accuracy, both in the flume and in the field (at $z=10 \mathrm{~cm}$ above the bed). In contrast, shear stress is estimated indirectly assuming a log velocity profile, but such profiles are only present during a portion of the tide, when there are no accelerating or decelerating tidal currents (Collins et al. 1981, Widdows \& Salkeld unpubl. obs.).

Quantitative and qualitative changes in the properties of the surface sediment ( $2 \mathrm{~cm}$ depth) and the resuspended particles in the flume were also measured. These include: size fraction analysis (by wet sieving for $>63 \mu \mathrm{m}$ diameter and Coulter Counter ${ }^{\circledR}$ Multisizer analysis for 2 to $63 \mu \mathrm{m}$ ), chlorophyll a (chl a) (by highperformance liquid chromatography [HPLC] following acetone extraction; Lucas \& Holligan 1999), colloidal carbohydrates (by the phenol-sulphuric acid method; Underwood et al. 1995), particulate organic carbon and nitrogen (using a Carlo Erba NA 1500 Analyser; Verardo et al, 1990), \% particulate organic matter (POM; by loss on ignition at $450^{\circ} \mathrm{C}$ ), bulk density (mass of wet sediment/volume of wet sediment) and moisture content (mass of water/mass of dry sediment).

The benthic-pelagic flux of oxygen and ammonium was determined by sampling water into a $10 \mathrm{ml}$ glass syringe via side ports in the flume during Phase 1 . The oxygen concentration was measured with a radiometer oxygen sensor (E5046) held in a thermostated cell coupled to an oxygen meter and chart recorder. The electrode was calibrated daily with air-saturated water and oxygen-zero solution (Radiometer 54150). Ammonium was measured using the phenol-hypochlorite method of Solorzano (1969).

At the end of each experimental run, the sediment from the flume was sieved through a $0.5 \mathrm{~mm}$ mesh, the 
macrofauna preserved in Rose-Bengal in formalin $(8 \%$ after dilution) and subsequently sorted. The dominant suspension- and deposit-feeding bivalve species with a potential for bioturbation were identified, sized (shell length), counted and weighed (ash-free dry weight [AFDW]).

During the first field campaign the EM current meter (Valeport) and OBS were mounted $10 \mathrm{~cm}$ above the bed at Site 1 and current velocities and SPM recorded over a single tidal cycle (30 May 1996). The OBS readings were converted to SPM using the calibration curve derived from the flume experiments involving the resuspension of sediments from Site 1.

Statistical analysis of the data was performed using ANOVA, ANCOVA and Pearson correlation analysis with Bonferroni corrections to probabilities (Systat v. 7 for Windows).

\section{RESULTS}

\section{Sediment erosion}

The results from the annular flume studies showed marked spatial and temporal differences in the stability/erodability of sediments from the 4 sites on the Molenplaat tidal flat. Erosion potential of the sediments was measured in terms of mass eroded $\left(\mathrm{g} \mathrm{m}^{-2}\right)$. critical erosion velocity $\left(\bar{U}_{\text {crit }}\right)$, and both maximum and mean erosion rates $\left(E_{\max }\right.$ and $\left.E_{\text {mean }}: \mathrm{g} \mathrm{m}^{-2} \mathrm{~s}^{-1}\right)$ from the

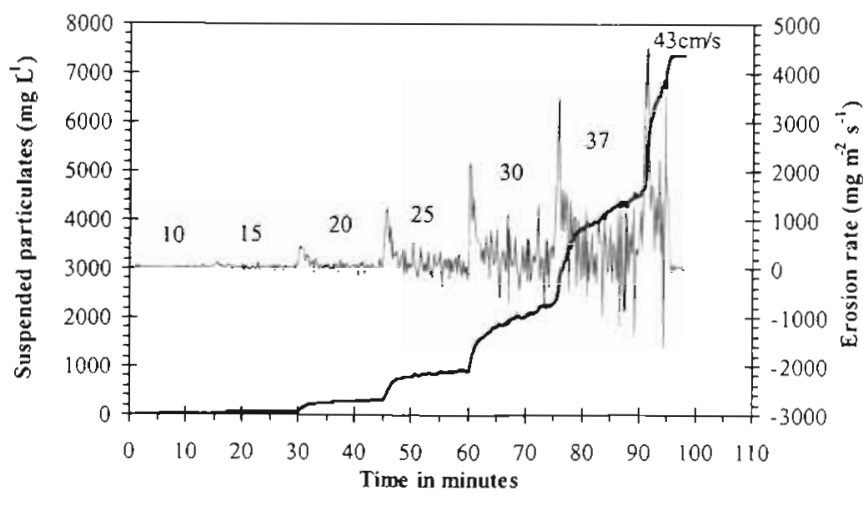

Fig. 3. Time course of suspended sediment concentration (thick line) and erosion rate (thin line) following a step-wise increase in free-stream current velocities between 10 and $43 \mathrm{~cm} \mathrm{~s}^{-1}$ (Site 2, September 1996)

bed at each current velocity/bed shear stress (for details see Widdows et al. 1998a,b). A representative time course of SPM concentration and erosion rate, in response to step-wise increases in current velocity, is illustrated in Fig. 3 (Phase 2: Site 2, September 1996).

Spatial differences in mass of sediment eroded in June and September are presented in Fig. 4A,B and other aspects of sediment stability are summarised in Table 1. ANCOVA, based on regressions between log mass eroded and current velocity (Fig. 5A: linear relationship between 20 and $43 \mathrm{~cm} \mathrm{~s}^{-1}$; Fig. 5B: linear relationship between 15 and $30 \mathrm{~cm} \mathrm{~s}^{-1}$ ), demonstrated that

Table 1. Spatial and temporal variation in sediment stability at 4 sites on the Molenplaat tidal flat (Westerschelde). Summary of sediment stability measurements: mass eroded $\left(\mathrm{g} \mathrm{m}^{-2}\right)$ at a 'standardised current velocity' of $30 \mathrm{~cm} \mathrm{~s}^{-1}$, max and mean erosion rate $\left(E_{\max }, E_{\text {mean }}: \mathrm{g} \mathrm{m}^{-2} \mathrm{~s}^{-1}\right)$ at $30 \mathrm{~cm} \mathrm{~s}^{-1}$, and critical erosion velocity $\left(\vec{U}_{\mathrm{crit}}: \mathrm{cm} \mathrm{s}^{-1}\right)$ defined as the current velocity $(x)$ required to increase suspended particulate matter (SPM) concentration $(y)$ above a threshold of $50 \mathrm{mg} \mathrm{l}^{-1}$. Measures of sediment stability are presented for a 'standardised' current velocity of $30 \mathrm{~cm} \mathrm{~s}^{-1}$ This was chosen for intra- and inter-site comparisons because $30 \mathrm{~cm} \mathrm{~s}^{-1}$ was above or near the maximum recorded critical erosion thresholds and was within the range of current velocities observed on the Molenplaat tidal flat. However, similar conclusions were apparent at 25 and $37 \mathrm{~cm} \mathrm{~s}^{-1}$. Mean values \pm range where $\mathrm{n}=2$ replicate flume experiments.

\begin{tabular}{|c|c|c|c|c|c|}
\hline Site & $\begin{array}{l}\text { Mass eroded at } \\
30 \mathrm{~cm} \mathrm{~s}^{-1} \\
\left(\mathrm{~g} \mathrm{~m}^{-2}\right)\end{array}$ & $\begin{array}{c}E_{\max } \text { at } 30 \mathrm{~cm} \mathrm{~s}^{-1} \\
\left(\mathrm{~g} \mathrm{~m}^{-2} \mathrm{~s}^{-1}\right)\end{array}$ & $\begin{array}{c}E_{\text {mean }} \text { at } 30 \mathrm{~cm} \mathrm{~s}^{-1} \\
\left(g \mathrm{~m}^{-2} \mathrm{~s}^{-1}\right)\end{array}$ & $\begin{array}{l}\text { Equation describing } \\
\text { SPM }\left(y: \mathrm{mg} \mathrm{l}^{-1}\right) \text { vs current } \\
\text { velocity }\left(x: \mathrm{cm} \mathrm{s}^{-1}\right)\end{array}$ & $\bar{U}_{\mathrm{cnt}}\left(\mathrm{cm} \mathrm{s}^{-1}\right)$ \\
\hline \multicolumn{6}{|c|}{ Ecoflat 1: May-June 1996} \\
\hline 1 & $65 \pm 11$ & $0.28 \pm 0.05$ & $0.045 \pm 0.005$ & $y=0.0049 e^{0.3261 x}$ & $28.2 \pm 1.6$ \\
\hline 2 (in situ) & - & 0.04 & - & - & -30 \\
\hline 2 & 29 & 0.10 & 0.03 & $y=0.0867 \mathrm{e}^{0.2276 x}$ & 27.9 \\
\hline 3 & 6.8 & 0.05 & 0.01 & $y=0.0100 e^{0.2462 x}$ & 34.6 \\
\hline 5 & 39.5 & 0.43 & 0.03 & $y=0.5260 e^{01676 x}$ & 27.2 \\
\hline \multicolumn{6}{|c|}{ Ecoflat 2: August-September 1996} \\
\hline 1 & $2068 \pm 98$ & $6.02 \pm 0.31$ & $2.00 \pm 0.32$ & $y=1.2668 \mathrm{e}^{0.3055 x}$ & $11.95 \pm 0.9$ \\
\hline 2 & $390 \pm 73$ & $1.67 \pm 0.44$ & $0.33 \pm 0.05$ & $y=1.0227 e^{0.2556 x}$ & $15.3 \pm 0.9$ \\
\hline 3 & $457 \pm 91$ & $2.15 \pm 0.14$ & $0.51 \pm 0.14$ & $y=0.0384 \mathrm{e}^{0.3734 x}$ & $19.2 \pm 0.1$ \\
\hline $3^{a}$ & 216 & 0.60 & 0.20 & $y=0.0837 e^{0.3155 x}$ & 20.3 \\
\hline 5 & $943 \pm 154$ & 7.49 & 1.08 & $y=1.2588 \mathrm{e}^{0.2681 x}$ & $13.7 \pm 0.9$ \\
\hline
\end{tabular}



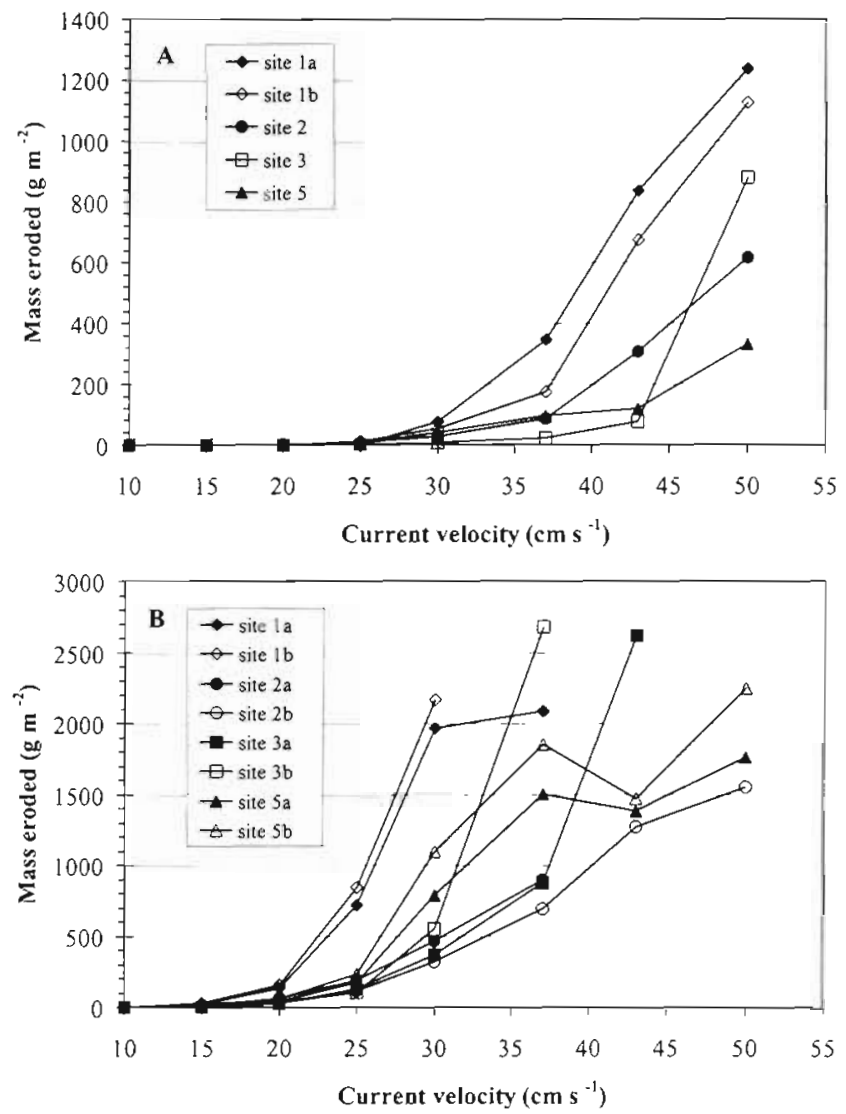

Fig. 4. Relationships between current velocity and mass of sediment eroded $\left(\mathrm{g} \mathrm{m}^{-2}\right)$ for sites on the Molenplaat tidal flat. (A) Ecoflat 1,28 May to 7 June 1996; (B) Ecoflat 2, 27 August to 5 September 1996; $a$ and b refer to replicate flume experiments

there were no significant differences between replicates, but there were significant spatial and temporal differences. Significant temporal differences were recorded at all sites $(p<0.001)$ with the degree of erodability at least 1 order of magnitude higher in September 1996. A more conservative statistical analysis of the sediment mass eroded at a single current speed of $30 \mathrm{~cm} \mathrm{~s}^{-1}$ (Table 1) confirmed that temporal differences were highly significant (ANOVA, $p<0.001$ ) and that the central sites (Sites 2 and 3) had a consistently lower erosion potential $(p<0.001)$ than Sites 1 and 5. Temporal changes in the sediment erosion curves for sites at the centre and edge of the Molenplaat are summarized in Fig. 6.

The $E_{\text {mean }}$ at the different current velocities are presented in Table 2, and $E_{\max }$ and $E_{\operatorname{mean}}$ at a standardised current velocity of $30 \mathrm{~cm} \mathrm{~s}^{-1}$ in Table 1 . Both $E_{\max }$ and $E_{\text {mean }}$ demonstrate that sediment at Sites 1 and 5 erode at a higher rate than at Sites 2 and 3. The initial onset of sediment erosion occurs between 15 and $20 \mathrm{~cm} \mathrm{~s}^{-1}$ in June and at $10 \mathrm{~cm} \mathrm{~s}^{-1}$ in September (Fig. 4). However,
$\bar{U}_{\mathrm{cnt}}$ calculated from the regression of log SPM against current speed provides a separation of the sites and a better quantitative measure of critical erosion velocity (Table 1). Therefore $\bar{U}_{c n 1}$, defined as the current velocity required to increase SPM concentrations in the flume above a threshold of $50 \mathrm{mg} \mathrm{l}^{-1}$, ranges from $26.5-34.6 \mathrm{~cm} \mathrm{~s}^{-1}$ in June to $11.0-20.3 \mathrm{~cm} \mathrm{~s}^{-1}$ in September. ANOVA showed that Site 3 had a consistently higher $\bar{U}_{\text {cnt }}(p<0.001)$. In September the $\bar{U}_{\text {crit }}$ was ca $50 \%$ lower at all sites, highlighting the markedly higher sediment erodability compared with June (ANOVA, p < 0.001).

Although Site 3 showed the greatest sediment stability (i.e. high $\bar{U}_{\text {crit }}$ and lower mass eroded and lower erosion rates) up to $30 \mathrm{~cm} \mathrm{~s}^{-1}$, at currents velocities above $43 \mathrm{~cm} \mathrm{~s}^{-1}$ in June and $37 \mathrm{~cm} \mathrm{~s}^{-1}$ in September the mass eroded and erosion rate increased rapidly, generally to values greater than the other sites. This increased erosion occurred at current velocities above the maximum recorded at Site $3\left(33 \mathrm{~cm} \mathrm{~s}^{-1}\right.$ on the ebb; Widdows unpubl. data 1997), and following the removal/resuspension of the stable surficial layer (microphytobenthic film
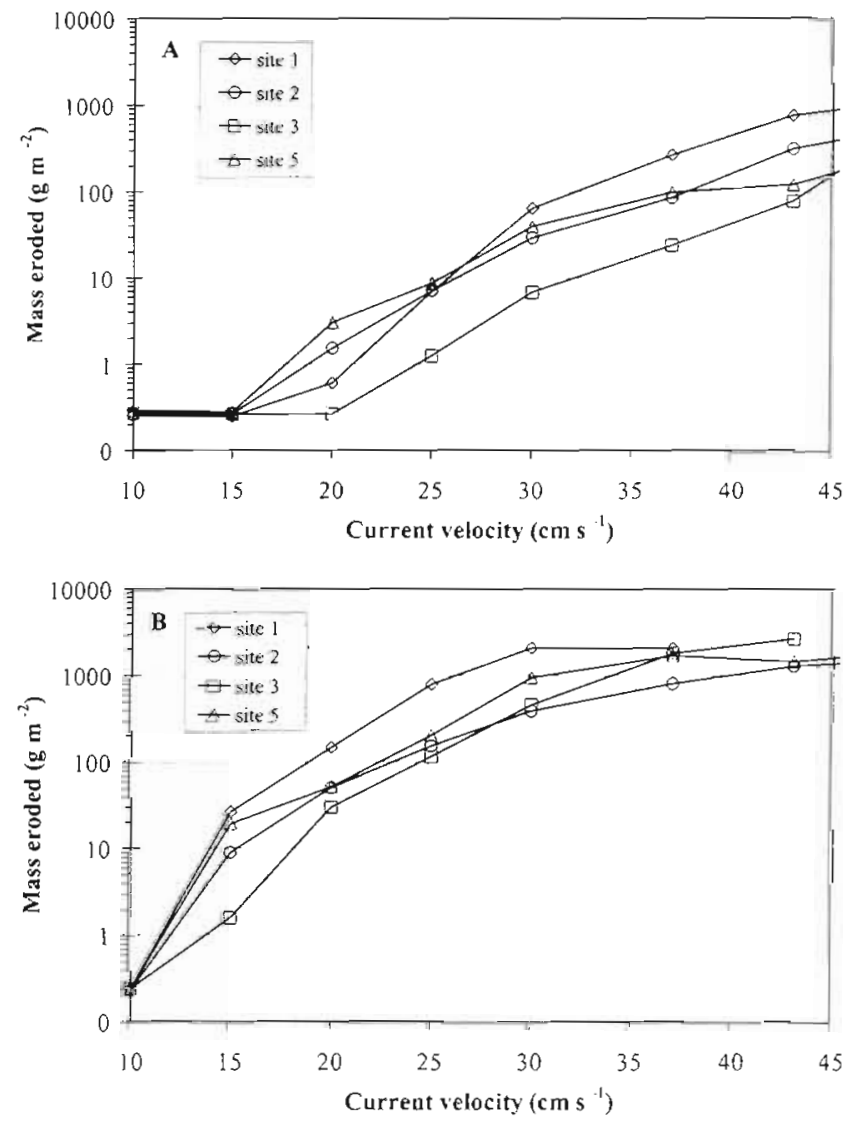

Fig. 5. Relationships between current velocity and log mass eroded $\left(\mathrm{g} \mathrm{m}^{-2}\right)$ for sites on the Molenplaat tidal flat (A) Ecoflat 1.28 May to 7 June 1996 ; (B) Ecoflat 2, 27 August to 5 September 1996; mean of 2 replicate flume experiments 


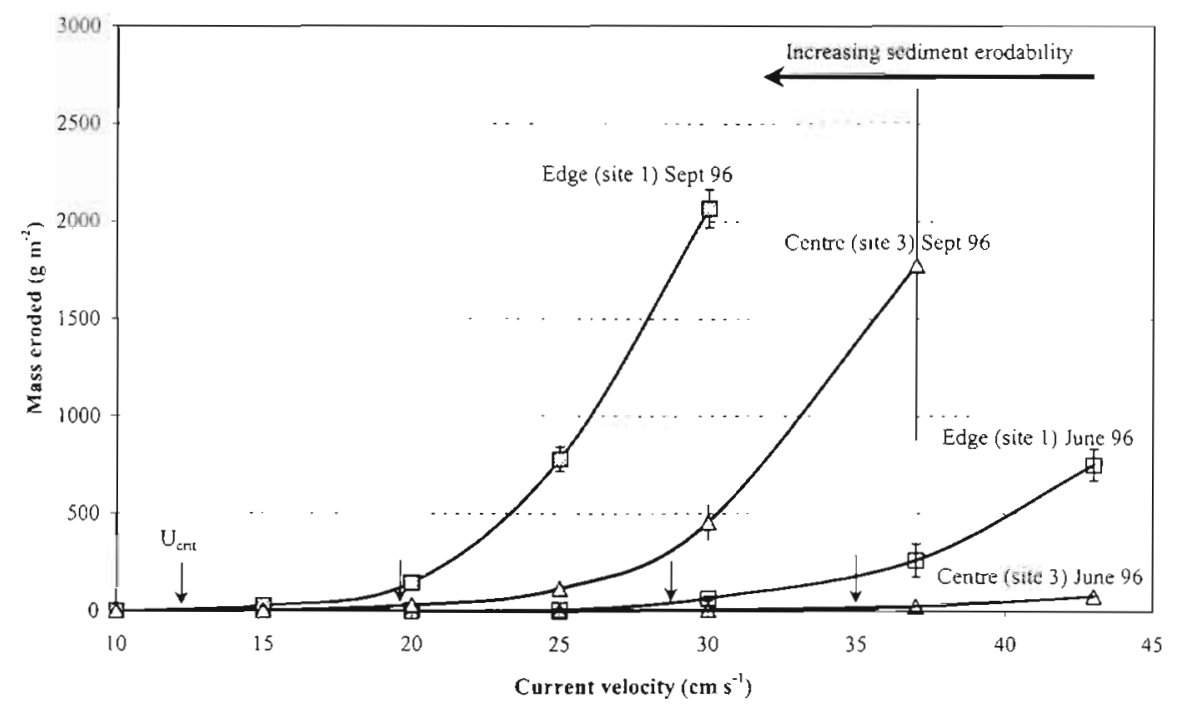

Fig. 6. Spatial and temporal changes in sediment erosion curves for the Molenplaat tidal flat. (Mean \pm range [ $\mathrm{n}=2$ replicate flume experiments] of mass eroded in relation to increasing current velocity; vertical arrows denote critical erosion velocities, $\bar{U}_{\text {crit }}$ for each curve)

and sticky cohesive sediment). In contrast to Site 3 , the sandy sediment from Site 5 showed the lowest stability and started to erode at a free-stream current velocity of $15 \mathrm{~cm} \mathrm{~s}^{-1}$ (a few rolling sand grains), with sand ripples forming and silt being resuspended from the bed at $20 \mathrm{~cm} \mathrm{~s}^{-1}$, and sand in suspension at $25 \mathrm{~cm} \mathrm{~s}^{-1}$. Above ca $40 \mathrm{~cm} \mathrm{~s}^{-1}$ the bed then flattened, thereby reducing the bed surface area and further reworking of the bed. This prevented further resuspension of fine silt or sand, and consequently there was even a slight reduction of SPM and a negative erosion rate (i.e. deposition) at $43 \mathrm{~cm} \mathrm{~s}^{-1}$ in September (Table 2). However, this occurs above the maximum recorded tidal current velocity at Site 5 (i.e. $35 \mathrm{~cm} \mathrm{~s}^{-1}$ on the floodi Widdows unpubl. data 1997).

\section{Sediment properties and nature of suspended material}

The physical properties of the surface sediment ( $2 \mathrm{~cm}$ depth) and the chl $a$ and colloidal carbohydrate content within the top $2 \mathrm{~mm}$ of sediment were mea-

Table 2. Mean erosion rates $\left(E_{\text {mean }}: \mathrm{mg} \mathrm{m}^{-2} \mathrm{~s}^{-1}\right)$ based on the initial $10 \mathrm{~min}$ at each current velocity for different sites on the Molenplaat tidal flat. Mean \pm range, where $n=2$ replicate flume experiments

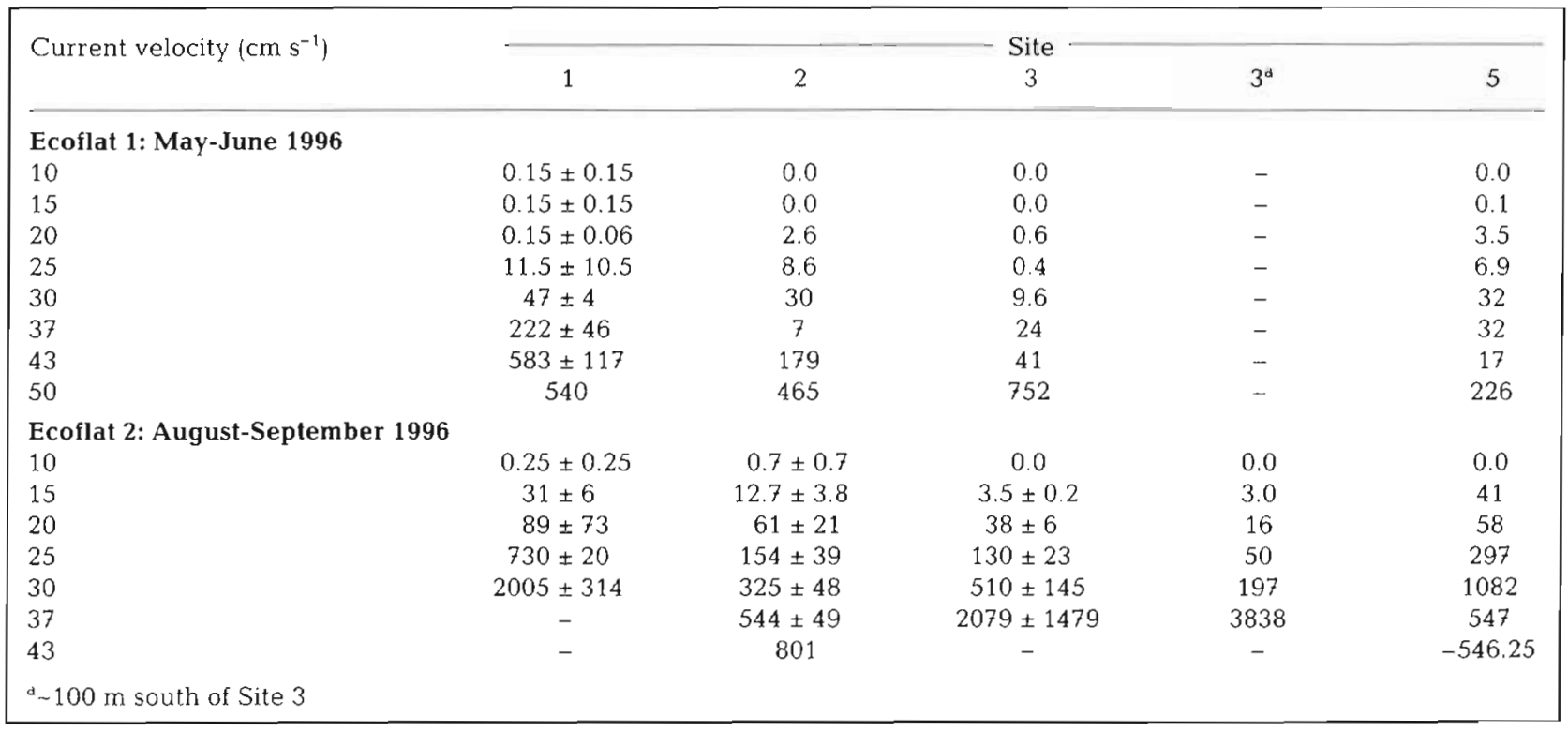


sured for each site (Table 3). The ranking of sites in terms of sand content $(\%>63 \mu \mathrm{m})$ was $5>1=3>2$ (ANOVA, $\mathrm{p}<0.001$ ) in both June and September, with no significant temporal differences. In terms of chl a and colloidal carbohydrate content there were highly significant temporal differences $(\mathrm{p}<0.001)$ and the site rankings were $5<3<2<1$ and $5<3<1<2$, respectively in May-June, and $5=1<2=3$ and $5<1<2<3$ respectively in August-September (ANOVA, $p<0.01$ ).

In addition, qualitative changes $(\% \mathrm{POM}$, organic carbon:nitrogen, chl a) in the material eroded and suspended into the water column of the flume were determined at different current velocities. Examples of the nature of eroded and suspended material are presented for 2 sites (Sites 1 and 3) in June and September (Figs. $7 \& 8$ ). Site 1 is representative of the sandy edge of the tidal flat and Site 3 the central region with cohesive muddy sand. At Site 1 in June, chl $a$ in the water column increased rapidly as currents rose above $20 \mathrm{~cm} \mathrm{~s}^{-1}$ (Fig. 7A), reflecting the suspension of surficial benthic algae from less stable sandy sediments. However, the more dense sediment particles (SPM measured by OBS) did not resuspend markedly until currents increased above ca $30 \mathrm{~cm} \mathrm{~s}^{-1}$. In contrast, at the more stable Site 3 the erosion of benthic algae and sediment began at higher current velocities, 25 and $37 \mathrm{~cm} \mathrm{~s}^{-1}$ respectively. Conse- quently, the flux of benthic algae into the water column in response to a current velocity of $30 \mathrm{~cm} \mathrm{~s}^{-1}$ was 9-fold higher at site 1 compared to Site 3 (Fig. 7), while the chl a concentration in the surficial sediments was only 1.4 -fold higher at Site 1 (Table 3 ). The resuspension of sediment and benthic algae was accompanied by a 3 -fold decline in the \%POM in the SPM, while the organic $\mathrm{C}: \mathrm{N}$ shows little change. However, the total $\mathrm{C}: \mathrm{N}$ increased from 11 by $2-$ to 3 -fold, presumably due to the resuspension of fine calcareous material. In September a similar response occurred, although the erosion and suspension of sediment and chl a occurred at a lower current velocity compared to June (chl a at 10 and $15 \mathrm{~cm} \mathrm{~s}^{-1}$ at Sites 1 and 3, and sediment at approximately $15 \mathrm{~cm}$ $\mathrm{s}^{-1}$ ). Therefore the benthic algae appear to have a slightly lower critical erosion velocity compared to the sediment particles.

The median size of fine particles in suspension (i.e. $<63 \mu \mathrm{m}$ as measured by Coulter Counter) increased with increasing current velocity, from 7-9.5 $\mu \mathrm{m}$ at $10 \mathrm{~cm} \mathrm{~s}^{-1}$ to $12-17.5 \mu \mathrm{m}$ at $37 \mathrm{~cm} \mathrm{~s}^{-1}$ in May-June with no clear differences between sites. In August-September the median size increased from $5-7 \mu \mathrm{m}$ at $10 \mathrm{~cm} \mathrm{~s}^{-1}$ to $9-20 \mu \mathrm{m}$ at $37 \mathrm{~cm} \mathrm{~s}^{-1}$ with sediments from Sites 1,2 and 3 producing larger particles (median $>16 \mu \mathrm{m}$ ) than Site 5 (median $9-11 \mu \mathrm{m}$ ).

Table 3. Physical and chemical properties of surface sediment. (All measurements are for sediment sampled to a depth of $2 \mathrm{~cm}$, except for the chemical analyses of $\mathrm{chl} a$ and carbohydrates, which are representative of 0 to $2 \mathrm{~mm}$ depth; mean of 3 replicates)

\begin{tabular}{|c|c|c|c|c|c|c|c|c|}
\hline Site & $\begin{array}{c}\text { Date } \\
\text { (d/mo/yr) }\end{array}$ & $\begin{array}{c}\text { Bulk } \\
\text { density } \\
\left(\mathrm{g} \mathrm{cm}^{-3}\right)\end{array}$ & $\begin{array}{c}\text { Moisture } \\
\text { content }(\% \mathrm{~g} \\
\left.\text { water } \mathrm{g}^{-1}\right)\end{array}$ & $\begin{array}{c}\% \text { of } \\
\text { sediment } \\
>63 \mu \mathrm{m}\end{array}$ & $\begin{array}{l}\% \text { POM } \\
\text { in total } \\
\text { sediment }\end{array}$ & $\begin{array}{c}\% \mathrm{POM} \\
\text { in }<63 \mu \mathrm{m} \\
\text { fraction }\end{array}$ & $\begin{array}{c}\text { Chlorophyll } \\
\left(\mu \mathrm{g} \mathrm{g}^{-1}\right) \\
\text { dry mass }\end{array}$ & $\begin{array}{c}\text { Carbohy- } \\
\text { drates }\left(\mu \mathrm{g}^{-1}\right. \\
\text { dry mass }\end{array}$ \\
\hline \multicolumn{9}{|c|}{ Ecoflat 1: May-June 1996} \\
\hline 1 & $31 / 5 / 96$ & 1.80 & 33.4 & 87.7 & 1.11 & 5.3 & 33.5 & 148 \\
\hline 1 & $1 / 6 / 96$ & 1.77 & 35.3 & 85.8 & 1.23 & 4.3 & 37.6 & 187 \\
\hline 2 & $29 / 5 / 96$ & 1.75 & 41.7 & 71.3 & 1.34 & 3.6 & 28.1 & 349 \\
\hline 2 & $3 / 6 / 96$ & 1.65 & 56.5 & 65.2 & 1.81 & 4.1 & 34.6 & 258 \\
\hline 3 & $30 / 5 / 96$ & 1.82 & 35.1 & 84.6 & 1.10 & 3.2 & 24.9 & 96 \\
\hline 3 & $4 / 6 / 96$ & 1.80 & 32.7 & 85.6 & 1.22 & 4.1 & 23.8 & 121 \\
\hline 5 & $29 / 5 / 96$ & 1.79 & 25.7 & 99.5 & 0.45 & 8.0 & 1.25 & 14 \\
\hline \multicolumn{9}{|c|}{ Ecoflat 2: August-September 1996} \\
\hline 1 & $2 / 9 / 96$ & 1.85 & 30.6 & 90.8 & 1.0 & 6.3 & 2.33 & 12 \\
\hline 1 & $2 / 9 / 96$ & 1.86 & 26.3 & 91.9 & 1.0 & 6.2 & - & - \\
\hline 2 & $27 / 8 / 96$ & 1.66 & 52.5 & 57.8 & 3.2 & 5.0 & 7.87 & 22 \\
\hline 2 & $29 / 8 / 96$ & 1.67 & 50.7 & 64.1 & 2.9 & 5.9 & 4.15 & 11 \\
\hline 2 & $2 / 9 / 96$ & 1.70 & 46.4 & 66.4 & 2.8 & 5.2 & 2.61 & 39 \\
\hline 2 & $4 / 9 / 96$ & 1.72 & 44.5 & 69.9 & 2.8 & 5.5 & 5.42 & 42 \\
\hline 3 & $3 / 9 / 96$ & 1.84 & 29.4 & 89.2 & 1.4 & 5.7 & 6.37 & 79 \\
\hline 3 & $3 / 9 / 96$ & 1.81 & 27.4 & 89.7 & 1.3 & 5.0 & - & - \\
\hline $3^{\mathrm{d}}$ & $30 / 8 / 96$ & 1.85 & 27.6 & 88.1 & 1.0 & 3.5 & 1.92 & 42 \\
\hline 5 & $27 / 8 / 96$ & 1.77 & 24.9 & 98.8 & 0.7 & 8.4 & $\begin{array}{l}1.32 \\
1.46\end{array}$ & 0.5 \\
\hline 5 & $28 / 8 / 96^{b}$ & 1.76 & 24.2 & 99.4 & 0.6 & 8.4 & - & - \\
\hline
\end{tabular}



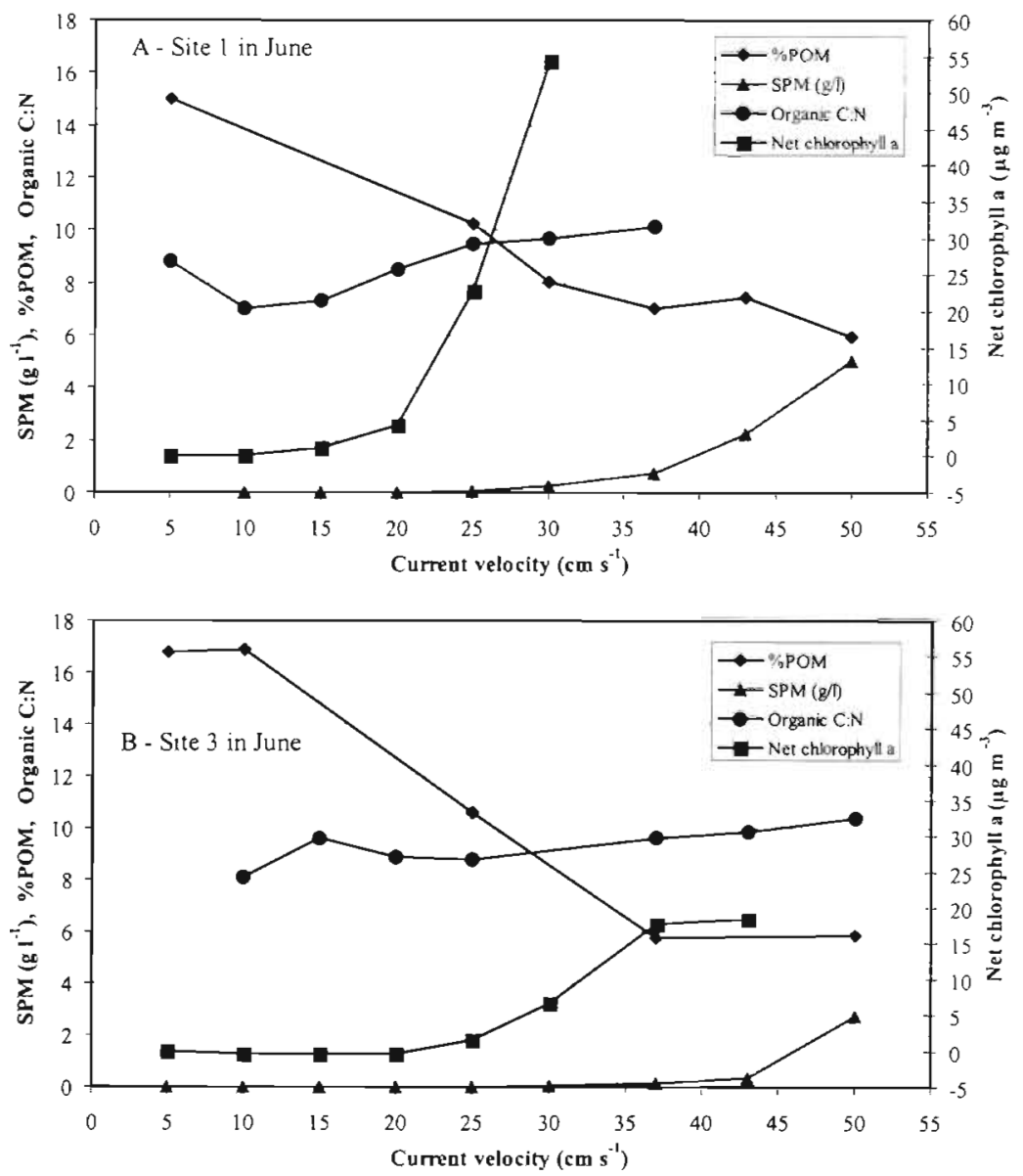

Fig. 7. Qualitative and quantitative changes in suspended particulate matter (SPM) with increasing current velocity. (A) Site 1 (edge of tidal flat) in June 1996; (B) Site 3 (centre of tidal flat) in June 1996. POM: particulate organic matter

\section{Benthic bivalves}

The density and biomass of suspension- and depositfeeding bivalves within the sediment of the flume experiments in both campaigns are summarised in Table 4. In May-June, the density and biomass of $M y a$ arenaria and Macoma balthica were similar at Sites 1 , 2 and 3 and were absent from the sandy Site 5. The highest densities of Cerastoderma edule were at the central Sites 2 and 3, with lower numbers at Site 1, and they were absent at Site 5.

In August-September, there was a lower density of Mya arenaria at Sites 1,2 and 3, but the biomass was higher than June due to 3 mo of summer growth. In contrast, Macoma balthica and Cerastoderma edule were present at all sites, including Site 5, and at higher densities (approx. 5- to 10-fold) due to summer recruitment, but without increasing the biomass markedly. The exception was Site 1, where $C$. edule was at lower densities or absent. Scrobicularia plana was also pre- sent at Sites 1, 2 and 3 in September and was particularly abundant at Site 3 .

Cohort analysis of these bivalves showed that they had grown significantly during the summer (Mya arenaria from 10 to $20 \mathrm{~mm}$ between May and September; Macoma balthica from 5 to $14 \mathrm{~mm}$; Cerastoderma edule from 5 to $20 \mathrm{~mm}$ ).

\section{Field versus flume measurements}

The changes in current velocity and SPM, measured over a single tidal cycle at Site 1 on the 30 May 1996, are illustrated in Fig. 9. At this site the currents are flood dominated, peaking at $33 \mathrm{~cm}$ $\mathrm{s}^{-1}$ within $30 \mathrm{~min}$ of flooding, and then declining rapidly to slack water. This coincided with a peak in the SPM of $500 \mathrm{mg} \mathrm{l}^{-1}$ in the shallow flood water, a depth comparable to that of the flume. SPM then rapidly declined to a relatively constant concentration and only increased slightly to $75 \mathrm{mg} \mathrm{l}^{-1}$ when the currents rapidly increased to a maximum of $21 \mathrm{~cm} \mathrm{~s}^{-1}$ on the ebb tide.

A plot of these data as SPM concentration versus current velocity (Fig. 10) shows good agreement between the observed (field) and predicted (flume) SPM for Site 1 . The $\bar{U}_{\text {cnt }}$ occurs between 22 and $27 \mathrm{~cm} \mathrm{~s}^{-1}$, and above this the SPM increases logarithmically with current velocity. At $30 \mathrm{~cm} \mathrm{~s}^{-1}$ the observed SPM in the field is $232 \mathrm{mg} \mathrm{l}^{-1}$ and flume results predicted $241 \mathrm{mg}$ $1^{-1}$, and, even when using the equation to extrapolate beyond the field data to higher than observed current velocities, there is close agreement between the field and flume data (at $43 \mathrm{~cm} \mathrm{~s}^{-1}: 2566 \mathrm{mg} \mathrm{l}^{-1}$ [field] and $3136 \mathrm{mg} \mathrm{l}^{-1}$ [flume]).

\section{Suspension-feeding activity and biodeposition rate}

The spatial and temporal changes in net clearance rates $\left(\mathrm{l} \mathrm{h}^{-1}\right)$ and estimated biodeposition rates $\left(\mathrm{g} \mathrm{m}^{-2}\right.$ $\mathrm{h}^{-1}$ ) at the seasonally ambient SPM concentrations are presented in Table 5. In May-June 1996 the flux from the water column to the sediment was similar at Sites 1,2 and 3 , whereas the rate at the sandy Site 5 was more than 1 order of magnitude lower and just detectable. In August-September only Site 3 had a consistently high clearance and biodeposition rate. At 

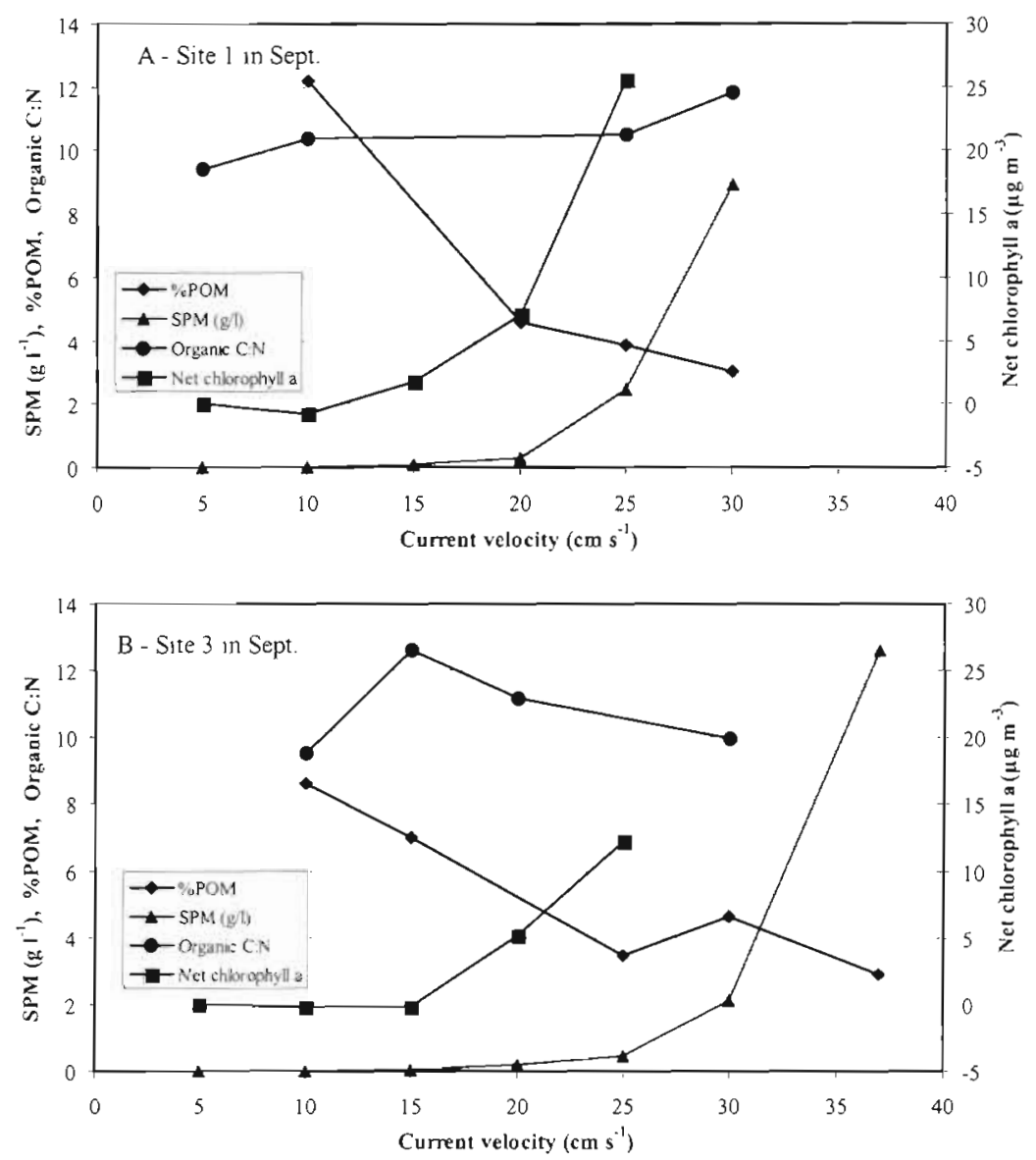

Fig. 8, Qualitative and quantitative changes in SPM with increasing current velocity. (A) Site 1 (edge of tidal flat) in September 1996; (B) Site 3 (centre of tidal flat) in September 1996 oxygen-consuming heterotrophs and the oxygen-producing photosynthetic autotrophs (i.e. major benthic algal films). Ammonium flux was not detected at Site 1 (i.e. no net flux) but there was uptake at Site 5 and production at Sites 2 and 3 . At Site 2, ammonium flux was also measured during the erosion phase and showed evidence of increasing efflux with increasing current velocity. In general, net ammonium flux reflected the reverse of oxygen flux, with net ammonium uptake due to the activities of benthic algae and net production due to the dominance of heterotrophic activity.

In August-September there was net uptake of oxygen and net production of ammonium at Sites 2 and 3, and Site 1 in terms of oxygen uptake only. This reflected the visual absence of major benthic algal films at this time, and the lower recorded chl a concentrations in the sediment (Table 3 ). Therefore, the balance had shifted to more heterotrophic-dominated activity at all sites in August-September. However, the lower oxygen uptake in September compared to June probably reflects the seasonally lower metabolic rates of macrofauna, particularly bivalves (Bayne \& Newell 1983).

\section{Statistical analysis}

Site 2 a low rate was measured, but at all other sites there was no detectable rate of clearance above that of natural sedimentation. Biodeposition rates were based on the mean SPM at slack high water over the Molenplaat in June $\left(5 \mathrm{mg} \mathrm{l}^{-1}\right)$ and September (60 $\mathrm{mg}$ $\mathrm{l}^{-1}$ ) to reflect the effect of temporal changes in SPM on biodeposition rates. The results show that biodeposition rates in the centre of the tidal flat were 1 order of magnitude higher in the autumn compared to the spring, and this was due to the higher SPM rather than higher clearance rates of suspension feeders.

\section{Oxygen and ammonium flux}

The net fluxes of oxygen and ammonium across the sediment-water interface are presented in Table 6 . In May-June there was net uptake of oxygen at Sites 2 and 3 , but at the sandier Sites 1 and 5 there was net production. This reflected the balance between the
Analysis of the data for ECOFLAT 1 and 2 revealed the following significant correlations: sediment chl a versus colloidal carbohydrate $(\mathrm{r}=+0.91, \mathrm{p}<0.005)_{\text {i }}$ $\bar{U}_{\text {crit }}$ versus sediment chl $a$ and colloidal carbohydrate $(r=+0.85, p=0.01)$; clearance rate versus sediment chl a and colloidal carbohydrate $(r=+0.92 ; p<0.001)$ clearance rate versus Cerastoderma edule biomass ( $\mathrm{r}=$ $+0.91, p<0.001$ ) $C$. edule biomass versus sediment chl a and colloidal carbohydrate $(r=+0.82, p<0.05)_{\text {; }}$ Macoma balthica density versus mass eroded and $E_{\text {mean }}(\mathrm{r}=+0.88, \mathrm{p}=0.005)$.

\section{DISCUSSION}

The present flume studies have demonstrated marked and statistically significant differences in the spatial and temporal variation in the sediment erosion potential of the Molenplaat tidal flat. There were no 
Table 4 . Summary of bivalve density and biomass (mean \pm range $n=2$ )

\begin{tabular}{|c|c|c|c|c|c|}
\hline \multirow{2}{*}{\multicolumn{2}{|c|}{ Bivalve species }} & & & \multirow{2}{*}{ Site } & \multirow[b]{2}{*}{5} \\
\hline & & 1 & 2 & & \\
\hline \multicolumn{6}{|c|}{ Ecoflat 1: May-June 1996} \\
\hline Mya arenaria & $\begin{array}{l}\left(\mathrm{N} \mathrm{m}^{-2}\right) \\
\left(\mathrm{g} \mathrm{m}^{-2}\right)\end{array}$ & $\begin{array}{l}491 \pm 21 \\
5.03 \pm 0.59\end{array}$ & $\begin{array}{l}470 \pm 76 \\
3.63 \pm 0.30\end{array}$ & $\begin{aligned} 521 & \pm 68 \\
4.80 & \pm 0.12\end{aligned}$ & $\begin{array}{l}0 \\
0\end{array}$ \\
\hline Macoma balthica & $\begin{array}{l}\left(\mathrm{N} \mathrm{m}^{-2}\right) \\
\left(\mathrm{g} \mathrm{m}^{-2}\right)\end{array}$ & $\begin{array}{c}156 \pm 3 \\
10.36 \pm 1.5\end{array}$ & $\begin{aligned} 121 & \pm 27 \\
4.64 & \pm 0.41\end{aligned}$ & $\begin{aligned} 141 & \pm 29 \\
7.15 & \pm 0.70\end{aligned}$ & $\begin{array}{l}0 \\
0\end{array}$ \\
\hline Cerastoderma edule & $\begin{array}{l}\left(\mathrm{N} \mathrm{m}^{-2}\right) \\
\left(\mathrm{g} \mathrm{m}^{-2}\right)\end{array}$ & $\begin{array}{c}12 \pm 6 \\
4.72 \pm 2.77\end{array}$ & $\begin{aligned} 56 & \pm 9 \\
4.87 & \pm 0.11\end{aligned}$ & $\begin{aligned} 56 & \pm 3 \\
3.31 & \pm 0.11\end{aligned}$ & $\begin{array}{l}0 \\
0\end{array}$ \\
\hline Total $\mathrm{g} \mathrm{m}^{-2}$ & & $20.11 \pm 0.56$ & $13.14 \pm 0.21$ & $15.26 \pm 0.93$ & 0 \\
\hline \multicolumn{6}{|c|}{ Ecoflat 2: August-September 1996} \\
\hline Mya arenaria & $\begin{array}{l}\left(\mathrm{N} \mathrm{m}^{-2}\right) \\
\left(\mathrm{g} \mathrm{m}^{-2}\right)\end{array}$ & $\begin{aligned} 167 & \pm 67 \\
7.48 & \pm 2.45\end{aligned}$ & $\begin{aligned} 274 & \pm 79 \\
10.05 & \pm 3.96\end{aligned}$ & $\begin{array}{c}159 \pm 41 \\
5.75 \pm 0.75\end{array}$ & $\begin{array}{l}0 \\
0\end{array}$ \\
\hline \multirow[t]{2}{*}{ Macoma balthica } & $\left(\mathrm{N} \mathrm{m}^{-2}\right)$ & $785 \pm 44$ & $138 \pm 26$ & $470 \pm 105$ & $111 \pm 29$ \\
\hline & $\left(g \mathrm{~m}^{-2}\right)$ & $14.01 \pm 1.64$ & $2.13 \pm 0.53$ & $7.05 \pm 0.15$ & $0.83 \pm 0.46$ \\
\hline Cerastoderma edule & $\begin{array}{l}\left(\mathrm{N} \mathrm{m}^{-2}\right) \\
\left(\mathrm{g} \mathrm{m}^{-2}\right)\end{array}$ & $\begin{array}{c}6 \pm 6 \\
0.58 \pm 0.58\end{array}$ & $\begin{array}{c}267 \pm 102 \\
2.02 \pm 1.01\end{array}$ & $\begin{array}{c}743 \pm 179 \\
3.94 \pm 0.38\end{array}$ & $\begin{array}{r}12 \pm 0 \\
0.014 \pm 0\end{array}$ \\
\hline Scrobicularia plana & $\begin{array}{l}\left(\mathrm{N} \mathrm{m}^{-2}\right) \\
\left(\mathrm{g} \mathrm{m}^{-2}\right)\end{array}$ & $\begin{array}{c}12 \pm 0 \\
0.05 \pm 0.02\end{array}$ & $\begin{aligned} 15 & \pm 9 \\
1.18 & \pm 0.64\end{aligned}$ & $\begin{array}{c}106 \pm 65 \\
1.04 \pm 0.48\end{array}$ & $\begin{array}{l}0 \\
0\end{array}$ \\
\hline Total $\mathrm{g} \mathrm{m}^{-2}$ & & $22.12 \pm 4.65$ & $15.38 \pm 1.78$ & $17.78 \pm 1.50$ & $0.84 \pm 0.46$ \\
\hline
\end{tabular}

Fig. 9. Field measurement of current velocity ( $)$ and SPM at $10 \mathrm{~cm}$ above the bed over as tidal cycle at Site 1 on the Molenplaat. HW: highwater

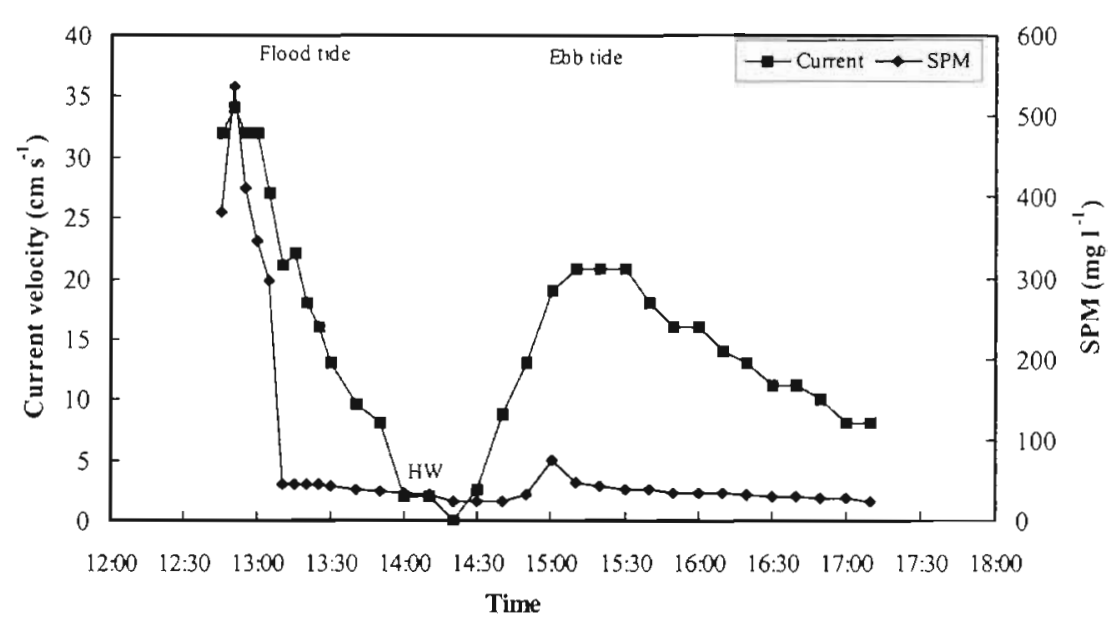

significant relationships ( $\mathrm{p}>0.1$ ) between measures of sediment erodability ( $\bar{U}_{\text {crit }}$, mass eroded, erosion rate) and the physical properties of the sediment $(\%$ sand, $\%$ POM, bulk density, \% water). This lack of correlation is consistent with the conclusions of previous studies in the Humber estuary (Widdows et al. 1998b). The statistically and biologically significant correlations recorded in the present study were primarily between (1) $\bar{U}_{\text {crt }}$ versus chl a and carbohydrate concentration in the sediment, reflecting the stabilising role of the microphytobenthos; and (2) erodability (mass eroded, erosion rate) versus the density of Macoma balthica, reflecting the destabilising role of these surface deposit-feeding clams. This interpretation of field data is consistent with previously established relationships

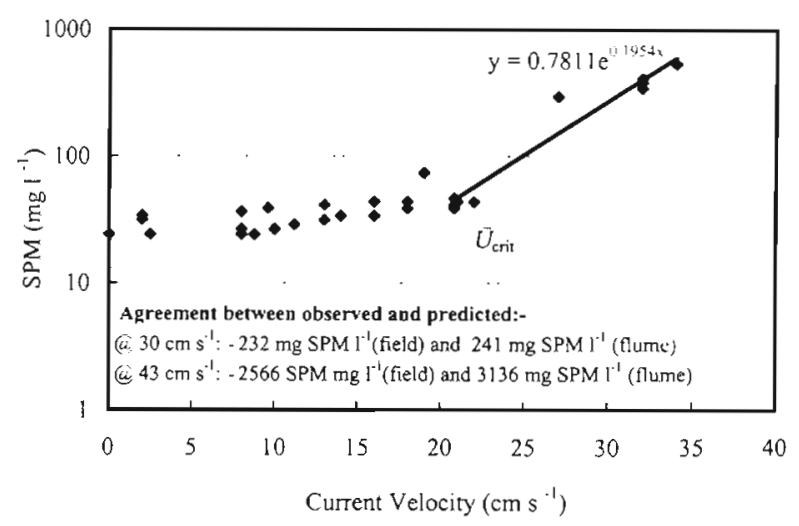

Fig. 10. Relationship between log SPM and current velocity with regression line drawn for data above the $\bar{U}_{\text {crit }}$ (data from Fig. 9) 
Table 5. Suspension-feeding activity (clearance rates) and biodeposition rates based on the ambient SPM concentrations in June $\left(5 \mathrm{mg} \mathrm{l}^{-1}\right)$ and September $\left(60 \mathrm{mg} \mathrm{l}^{-1}\right)$. Mean \pm range, where $n=2$ replicate flume experiments. nd: not detectable

\begin{tabular}{|lcc|}
\hline Site & $\begin{array}{c}\text { Net clearance rate } \\
\text { in flume }\left(\mathrm{h} \mathrm{h}^{-1}\right)\end{array}$ & $\begin{array}{c}\text { Net biodeposition rate } \\
\left(\mathrm{g} \mathrm{m}^{-2} \mathrm{~h}^{-1}\right) \text { at } 5{\mathrm{mg} \mathrm{SPM}^{-1}}^{-1}\end{array}$ \\
\hline Ecoflat 1: May-June 1996 & $0.64 \pm 0.05$ \\
1 & $21.7 \pm 1.7$ & 0.85 \\
2 & 28.9 & $0.57 \pm 0.19$ \\
3 & $19.3 \pm 6.6$ & 0.05 \\
5 & 1.5 & \\
Ecoflat 2: August-September 1996 & 0 \\
1 & nd & 2.82 \\
2 & 8.0 & $7.65 \pm 0.81$ \\
3 & $21.68 \pm 2.29$ & 0 \\
5 & nd & \\
\hline
\end{tabular}

and the mechanistic understanding derived from controlled flume experiments (Sutherland et al. 1998a, Widdows et al. 1998c, Willows et al. 1998).

\section{Bio-stabilisation of sediment}

Critical erosion thresholds were considerably higher in May-June $\left(\bar{U}_{\text {cril }}: 27\right.$ to $\left.35 \mathrm{~cm} \mathrm{~s}^{-1}\right)$, compared to August-September ( $\bar{U}_{\text {cril }}: 11$ to $\left.20 \mathrm{~cm} \mathrm{~s}^{-1}\right)$, and this was associated with the presence of very visible benthic algal films, as supported by the markedly higher chl a and colloidal carbohydrate levels in the sediment in the spring. However, once the benthic algal film is stripped away by currents above the $\bar{U}_{\text {crit }}$ then the underlying sediment is readily eroded. This was par- ticularly apparent at the central Site 3 (Fig. 4). Even at the sandy sites on the edge of the tidal flat (Sites 1 and 5), the presence of well-developed benthic biofilms enhanced sediment stability in the spring. Although the sediment at Site 5 did not have a very visible benthic algal film in comparison to Site 1, its enhanced sediment stability was consistent with the 'crusty' nature of the surface sediment during air exposure. This may be indicative of the presence of epipsammic algae and filamentous cyanobacteria, which are known to bind sand grains and reduce the erodability of sandy sediment (Stal 1994).

The observed relationships between chl a or carbohydrates and measures of sediment stability, such as $\bar{U}_{\text {crit }}$ in this study, are consistent with the largely qualitative and a few quantitative findings of previous studies (reviewed by Paterson 1997). Grant \& Gust (1987) using a quantitative approach showed similar relationships between critical erosion (friction) velocity $(U \cdot \mathrm{cnt}$ ) and chl a $(\mathrm{r}=+0.80)$ and colloidal carbohydrate $(r=+0.77)$. More recently, Sutherland et al. (1998b) demonstrated strong relationships between critical erosion thresholds and sediment chl $a(\mathrm{r}=+0.97)$ and colloidal carbohydrate $(r=+0.92)$ during field deployments of a benthic annular flume in Nova Scotia.

In spite of the presence and activity of infaunal bivalves (Macoma balthica, Cerastoderma edule and Mya arenaria) in June and September (Table 4), the overall balance between the 'bio-stabilisers' and the 'bio-destabilisers' appears to be dominated by the stabilising influence of the microphytobenthos in June. The presence of major benthic algal films during the spring of 1996 indicates that their growth rate was greater than the grazing rate by surface deposit feeders such as $M$. balthica and Pygospio elegans.

Table 6. Rates of oxygen and ammonium fluxes across sediment-water interface as measured in the flume at a current velocity of $5 \mathrm{~cm} \mathrm{~s}^{-1}\left(\mathrm{NH}_{4}\right.$ flux associated with erosion also measured at Site 2). Experimental conditions: $18^{\circ} \mathrm{C}, 24$ psu, ambient light. Mean \pm range, where $n=2$ replicate flume experiments; + : production; -: uptake; nd: not detected, i.e. $<3 \times$ rate of change in control

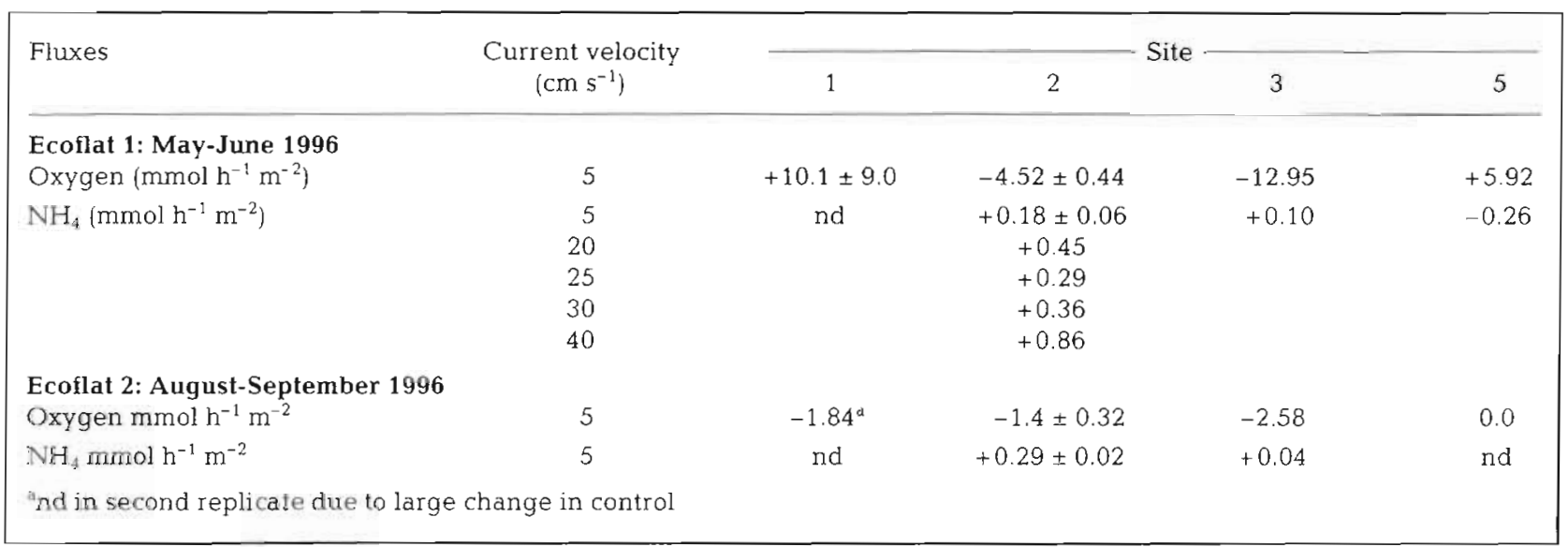


The small tube-building spionid polychaete Pygospio elegans is another member of the benthic community that may exert a stabilising effect on the sediment, particularly at high densities (Eckman et al. 1981). Spionid tubes are fragile and difficult to quantify but were observed in high density patches at Sites 2 and 3 (up to $14000 \mathrm{~m}^{-2}$ in June 1996, based on analysis of video recordings of the sediment in the flume). Detailed analysis of the faunal composition of the Molenplaat in 1996 has shown P. elegans to occur at maximum densities in June compared to September; particularly at Sites 2 and 3 (max. of $32000 \mathrm{~m}^{-2}$ ), with lower densities at Sites 1 and 5 (P. Herman et al. unpubl. data). Quantification of the impact of spionids on the sediment stability is at present experimentally untested, but it seems probable that these tubes, when present at high densities, will significantly enhance stability by reducing the effective shear stress on the bed. Video recordings showed that as the surface sediment erodes, the tops of the flexible tubes bend over in the current and serve to physically protect the sediment and increase the height of the viscous sublayer and boundary layer, thus reducing erosion.

\section{Bio-destabilisation of sediment}

Temporal and spatial differences in sediment erodability appear to reflect differences in the biological properties of the sediment on the Molenplaat, particularly the recruitment and growth of surface deposit-feeding bivalves, such as Macoma balthica and Scrobicularia plana, between June and September (Table 4). The observed correlation between sediment erodability (mass eroded, $E_{\text {mean }}$ ) and the density of $M$. balthica is consistent with previous field and laboratory measurements. Studies in the Humber estuary have shown a similar correlation between sediment erodability and the activity and density of $M$. balthica (Widdows et al. 1998b). More importantly, laboratory flume experiments have shown that bioturbation by the clam $M$. balthica causes a density-dependent increase in the erodability of the surface sediments (Widdows et al. 1998c). Furthermore, modelling studies have demonstrated the importance of $M$. balthica as a destabiliser of intertidal sediments (Willows et al. 1998).

Two other surface deposit feeders, Pygospio elegans and Hydrobia ulvae, were abundant on the Molenplaat in 1996 (P. Herman et al. unpubl. data). However, these species were at a higher density in June compared to September, and their feeding behaviour is more grazing than bioturbation. Consequently, they do not appear to destabilise the sediment to the same extent as Macoma balthica.

\section{Biodeposition and sediment properties}

The results show a significant relationship between clearance rate and Cerastoderma edule biomass ( $\mathrm{r}=$ $+0.91, p<0.001)$. In May-June there were high clearance rates at Sites 1, 2 and 3 where $C$. edule were moderately abundant. During the summer there was recruitment and growth of C. edule, resulting in a higher density, but similar biomass, in the central region (Sites 2 and 3). In September there were only measurable clearance rates at these central sites. The generally lower clearance rate in September is consistent with the recorded seasonal decline in clearance rate of $C$. edule from a maximum in the spring to a minimum in the autumn (Newell \& Bayne 1980). Mya arenaria. although present at a similar or slightly higher biomass than $C$. edule, appear to have lower suspension-feeding rates (Shumway et al. 1985, P. Salkeld unpubl. data) and therefore contribute less to the overall benthic community clearance rate.

The results also demonstrated a significant correlation between the clearance rate/biodeposition rate and the concentration of chl a and colloidal carbohydrates in the sediments $(\mathrm{r}=+0.92$ and 0.95 , respectively; $\mathrm{p}<$ 0.001 ). This relationship probably arises from the filtration of phytoplanktonic and any resuspended microphytobenthic organisms from the water column by suspension-feeding bivalves (e.g. Cerastoderma edule and Mya arenaria), and their deposition as faeces and pseudofaeces. Under conditions of increasing SPM (above a threshold of ca $5 \mathrm{mg} \mathrm{l}^{-1}$; Navarro \& Widdows 1997), excess material including phytoplankton and resuspended microphytobenthos may be rejected by the bivalve gills, loosely bound in mucus and ejected from the mantle cavity as pseudofaeces. Even mucusbound faecal pellets may contain undigested algal cells as part of the rejection pathway within the stomach (i.e. intestinal faeces, Widdows et al. 1979).

The measured clearance and biodeposition rates (at 5 and $60 \mathrm{mg} \mathrm{SPM} \mathrm{l}^{-1}$ ) in the central part of the Molenplaat, with the highest density of Cerastoderma edule, are comparable to rates recorded in other studies (e.g. $1.64 \mathrm{~g} \mathrm{~m}^{-2} \mathrm{~h}^{-1}$ for $78 \mathrm{ind} . \mathrm{m}^{-2}$ in the Oosterschelde at $20 \mathrm{mg} \mathrm{SPM} \mathrm{^{-1 }}$ : Smaal et al. 1986, and $6 \mathrm{~g} \mathrm{~m}^{-2} \mathrm{~h}^{-1}$ for 50 ind. $\mathrm{m}^{-2}$ in the Humber at $52 \mathrm{mg} \mathrm{SPM} \mathrm{l}^{-1}$ : Widdows et al. $1998 \mathrm{c}$ ). Previous studies have shown that as the clearance rate by $C$. edule gradually declines in response to increasing SPM, the mass filtered and deposited as faeces and pseudofaeces increases with SPM, reaching a maximum at ca $200 \mathrm{mg} \mathrm{SPM} \mathrm{I}^{-1}$ (Navarro \& Widdows 1997). Consequently, as the SPM increases from low values in the spring/summer to high values in the autumn/winter period, due to the physi$\mathrm{cal} /$ biological interaction (i.e. increased river flows and storms combined with a biologically mediated increase 
in sediment erodability), the biodeposition rates will increase. However, most of the material deposited during the period of slack high water, whether by the process of natural sedimentation or biodeposition, will be resuspended again when currents increase above the critical erosion threshold. Any retention and long-term incorporation of recently deposited material into the bed sediment will be dependent on the degree of mixing and vertical transport within the sediment involving important biological processes (e.g. deposit feeding, bioturbation and burrowing) by species such as Macoma balthica, $C$. edule, Heteromastus filiformis.

During the period from May-June to August-September there is evidence of a slight but consistent change in the properties of the sediment on the Molenplaat tidal flat. Table 3 shows an increase in the \%POM in the total sediment and in the $<63 \mu \mathrm{m}$ fraction. This probably reflects the biological activity within the sediment. particularly the processes of biodeposition which will enhance the flux of fine material from the water column to the sediment, as well as the process of bioturbation which will subsequently mix and trap this material in the sediment. The \%POM in the $<63 \mu \mathrm{m}$ fraction increased by an average of $41 \%$ between June and September for Sites 1,2 and 3, compared to only $5 \%$ for Site 5 with minimal suspension-and deposit-feeding activity. These findings support the observations of Austen (1997), who found that benthic fauna played an important role in modifying the composition of surficial sediments and established positive relationships between animal abundance and \% mud content and faecal pellet volume in tidal flats. Data for 1997 indicate that the \% POM in the fine fraction and the silt content of the Molenplaat subsequently decline over winter before increasing again during the spring-summer. This decline in the \% POM and silt particles is probably the result of increased physical disturbance (tidal currents/river flow and wind/wave action) combined with the reduced biological activity during the winter period (i.e. suspension feeding for deposition, bioturbation for sediment mixing, and productivity of benthic algae to enhance sediment binding).

During the second ECOFLAT field campaign, there was a major storm (Force 9 on 28 August 1996) and the main visual impact of this storm was to deposit a fine layer of sand grains on the sediment surface at Sites 2 and 3 . The surface was transformed from a very smooth to a slightly rippled surface (ca $5 \mathrm{~mm}$ height), but with little evidence of significant erosion or scouring of the sediment surface. However, after $24 \mathrm{~h}$ there was evidence of mixing and burial of the surface sediment, particularly by the faecal deposits of the abundant 'head-down' deposit feeder Heteromastus fillformis (13000 ind. $\mathrm{m}^{-2}$; P. Herman unpubl. data). After $3 \mathrm{~d}$ the surface had returned to its original appearance (i.e smooth surface with a high density of small polychaete tubes and faecal deposits and no evidence of sand grains on the surface). Table 3 presents observed changes in the physical and chemical properties at Site 2 over a period of $6 \mathrm{~d}$ post-storm. The time series shows an increase in the sand content (58 to $70 \%$ ), a decline in the \%POM ( 3.2 to $2.8 \%$ ), and a decline followed by a rise in chl $a$ and carbohydrates. Observations within the flume after erosion (Phase 2) and in the field (post-storm) highlight the adaptability and rapid recovery of the benthic biota following periods of physical disturbance.

When assessing the potential for sediment erosion and deposition at the Molenplaat sites and the relative balance between the 2 processes, it is apparent that the central Sites 2 and 3 have greater potential for fine sediment accumulation. At these sites, both the erosion rate is lower and the deposition rate is higher than the sites on the edge of the tidal flat. This applies in MayJune and August-September, and appears to be primarily the result of biological processes and the biological properties of the sediment.

The development of algal films on the tidal flat also provides some important positive feedback to both the benthic and planktonic algal communities, by reducing tidal sediment resuspension and turbidity, thereby increasing light penetration in the water column. The enhanced light penetration will therefore provide feedback and encourage both benthic and planktonic algal productivity. Any erosion of surficial sediments will result in microphytobenthic algae being made available to suspension feeders, but these animals will also serve to enhance algal sedimentation rate, particularly if deposited via rejection pathways as pseudofaeces or intestinal faeces.

\section{Conclusion}

In conclusion, this study has demonstrated: (1) Spatial and temporal variation in the sediment erodability of a tidal flat, which reflects changes in the overall balance between the major biological 'stabilisers' (microphytobenthos) and 'destabilisers' (bioturbating clams). Central sites were less erodable than those at the edge of the tidal flat, and sediment erosion potential was $>10$ - to 60-fold higher in September compared to June. (2) The microphytobenthos are eroded and suspended in the water column when flood and ebb tidal currents are greater than the critical erosion velocity. They are then made available to suspension feeders (e.g. Cerastoderma edule, Mya arenaria), but these filter feeders can also enhance the deposition of the microphytobenthos via pseudofaeces and intestinal faeces. Furthermore, the biodeposits of suspension feeders can alter 
the nature of the sediment. (3) Similar relationships between SPM and current velocity have been recorded in the field and in the annular flume. This indicates that flume studies reflect the processes occurring in the field, and can therefore play an important role in quantifying and understanding the role of biological and physical processes in benthic-pelagic exchanges and sediment dynamics.

Acknowledgements. We wish to thank R. N. Head at PML for the particulate $\mathrm{C}: \mathrm{N}$ analysis, staff of the Rijkswaterstaat and Netherlands Institute of Ecology for their support during the field campaigns, and particularly Dr Peter Herman and Prof Carlo Heip for coordinating the research project. This work is a contribution to the EU ELOISE Programme (ELOISE no. 106) in the framework of the ECOFLAT Project carried out under contract no. ENV4-CT96-0216.

\section{LITERATURE CITED}

Amos CL, Brylinsky $M$, Sutherland TF, O'Brien D, Lee S, Cramp A (1998) The stability of a mudflat in the Humber estuary, South Yorkshire, U.K. In: Black KS, Paterson DM, Cramp A (eds) Sedimentary processes in the intertidal zone, Vol 139. Special Publications, Geological Society, London, p 25-43

Austen I (1997) Temporal and spatial variation of biodepositsa preliminary investigation of the role of fecal pellets in the Sylt-Rømø tidal area. Helgol Meeresunters 51:281-294

Bayne BL, Newell RC (1983) Physiological energetics of marine molluscs. In: Saleuddin ASM, Wilbur KM (eds) The Mollusca, Vol. 4. Academic Press, New York, p 407-515

Black KS, Paterson DM (1997) Measurement of the erosion potential of cohesive marine sediments: a review of current in situ technology. J Mar Environ Engin 4:43-83

Collins MB, Amos CL, Evans G (1981) Observations of some sediment transport processes over intertidal flats in the Wash, UK, Vol 5. Special Publication, International Association of Sedimentologists, Oxford, p 81-98

Eckman JE, Nowell ARM, Jumars PA (1981) Sediment destabilization by animal tubes. J Mar Res 39:361-374

Fukada MK, Lick W (1980) The entrainment of cohesive sediment in freshwater. J Geophys Res 85:2813-2824

Grant J, Daborn GR (1994) The effects of bioturbation on sediment transport on an intertidal mudflat. Neth J Sea Res $32: 63-72$

Grant J, Gust G (1987) Prediction of coastal stability from photopigment content of mates of purple sulphur bacteria. Nature 330:244-246

Heip CHR, Goosen NK, Herman PMJ, Kromkamp J, Middelburg JJ, Soetaert K (1995) Production and consumption of biological particles in temperate tidal estuaries. Oceanogr Mar Biol Annu Rev 33:1-149

Lucas CH, Holligan. PM (1999) Nature and ecological implications of algal pigment diversity on the Molenplaat tidal flat (Westerschelde estuary, SW Netherlands). Mar Ecol Prog Ser 180:51-64

Maa JPY (1990) The bed shear stress of an annular sea-bed flume. In: Michaelis W (ed) Estuarine water quality management: monitoring, modelling and research. SpringerVerlag, Berlin, p 271-275

Navarro JM, Widdows J (1997) Feeding physiology of Cerastoderma edule (L.) in response to a wide range of seston concentrations. Mar Ecol Prog Ser 152:175-186
Newell RIE, Bayne BL (1980) Seasonal changes in the physiology, reproductive condition and carbohydrate content of the cockle Cardium (Cerastoderma) edule (Bivalvia: Cardidae). Mar Biol 56:11-19

Paterson DM (1989) Short-term changes in the erodibility of intertidal cohesive sediments related to the migratory behaviour of epipelic diatoms. Limnol Oceanogr 34: 223-234

Paterson DM (1997) Biological mediation of sediment erodibility: ecology and physical dynamics. In: Burt N, Parker R, Watts J (eds) Cohesive sediments. J Wiley, Chichester, p 215-229

Rhoads DC, Boyer LF (1982) The effects of marine benthos on physical properties of sediments: a successional perspective. In: McCall PL, Tevesz, MJS (eds) Animal-sediment relations: the biogenic alteration of sediments. Plenum Press, New York, p 3-52

Shumway SE, Cucci TL, Newell RC, Yentsch CM (1985) Particle selection, ingestion and absorption in filter-feeding bivalves. J Exp Mar Biol Ecol 91:77-92

Smaal AC, Verhagen JHG, Goosen J, Haas HA (1986) Interaction between seston quantity and quality and benthic suspension feeders in the Oosterschelde, the Netherlands Ophelia 26:385-399

Solorzano L (1969) Determination of ammonia in natural waters by the phenol-hypochlorite method. Limnol Oceanogr 14:799-801

Stal L (1994) Microbial mats: ecophysiological interactions related to biogenic sediment stabilization. In: Krumbein WE, Paterson DM, Stal L (eds) Biostabilization of sediments. Springer Verlag, Oldenburg, p 41-53

Sutherland TF, Grant $J$, Amos CL (1998a) The effect of carbohydrate production by the diatom Nitzschia curvilineata on the erodability of sediment. Limnol Oceanogr 43:65-72

Sutherland TF, Amos CL, Grant J (1998b) The effect of buoyant biofilms on the erodibility of sublittoral sediments of a temperate microtidal estuary. Limnol Oceanogr 43 $225-235$

Underwood GJC, Paterson DM, Parkes RJ (1995) The measurement of microbial carbohydrate exoplolymers from intertidal sediments. Limnol Oceanogr 40:1243-1253

Verardo DJ, Froelich PN, Mclntyre A (1990) Determination of organic carbon and nitrogen in marine sediments using the Carbo-Erba NA-1500 analyser. Deep-Sea Res 37: $157-165$

Widdows J, Fieth P, Worrall CM (1979) Relationships between seston, available food and feeding activity in the common mussel, Mytilus edulis. Mar Biol 50:195-207

Widdows J, Brinsley MD, Elliott M (1998a) Use of in situ flume to quantify particle flux (deposition rates and sediment erosion) for an intertidal mudflat in relation to changes in current velocity and benthic macrofauna. In: Black KS Paterson DM, Cramp A (eds) Sedimentary processes in the intertidal zone, Vol 139. Geological Society, Special Publications, London, p 85-97

Widdows J, Brinsley MD, Bowley N, Barrett C (1998b) A benthic annular flume for in situ measurement of suspension feeding/biodeposition rates and erosion potential of intertidal cohesive sediments. Estuar Coast Shelf Sci 46:27-38

Widdows J, Brinsley MD, Salkeld PN, Elliott M (1998c) Use of annular flumes to determine the influence of current velocity and biota on material flux at the sediment-water interface. Estuaries 21:552-559

Willows RI, Widdows J, Wood RG (1998) Influence of an infaunal bivalve on the erosion of an intertidal cohesive sediment: a flume and modeling study. Limnol Oceanogr 43: $1332-1343$ 